\begin{tabular}{c} 
Volume and Issues Obtainable at Center for Sustainability Research and Consultancy \\
Journal of Accounting and Finance in Emerging Economies \\
ISSN: 2518-0318 ISSN (E) 2518-8488 \\
Volume 6: Issue 2 June 2020 \\
CSRE \\
Journal homepage: www.publishing.globalcsrc.org/jafee \\
\hline
\end{tabular}

\title{
Oil Price Flux and Macroeconomy of Oil Exporters
}

\author{
${ }^{1}$ Madiha Riaz, ${ }^{2}$ Saeed-ur-Rahman, ${ }^{3}$ Shahzad Mushtaq, ${ }^{4}$ Aabeera Atta \\ ${ }^{1}$ Assistant Professor, Department of Economics, Ghazi University, D.G Khan, Pakistan, \\ mriaz@gudgk.edu.pk \\ ${ }^{2}$ Lecturer, Department of Economics, Ghazi University, D.G Khan, Pakistan, saeedurrahman16@ gmail.com \\ ${ }^{3}$ Lecturer, The Islamia University of Bahawalpur, Pakistan, mianb19@ yahoo.com \\ ${ }^{4}$ Lecturer, Ghazi University, D.G.Khan, Pakistan, beerarajpoot707@gmail.com
}

\begin{abstract}
ARTICLE DETAILS
History

Revised format: May 2020

Available Online: June 2020

\section{Keywords}

Oil Prices, Johansen Co-

integration, Error Correction

Mechanism, Inflation
\end{abstract}

JEL Classification

F42, F62, O11, O42

\begin{abstract}
Oil is an important energy source, embodies the largest commodity market in the world. Global economic performance has been highly correlated with oil price changes. The study considered 10 major oil exporters to measure the effect of oil price changes on their economies considering variables: Oil Prices (OP), Inflation (CPI), GDP deflator, Lending interest rate (IR), real interest rate (RIR), Official Exchange Rate (EX), and Net domestic credit (LDU). By applying Johansen Co-integration techniques, long run relationship among variables has been analyzed covering the time period from 1970 to 2019. In order to find the short run relationship, Error Correction Model (ECM) technique is used. Study affirmed that there exist a strong relation among economic variables and oil price fluctuations; however the intensity of relationship displays a variation. Oil prices are associated with GDP deflator and RIR significantly as compared to other variables. Moreover, it can be suggested that each country should observe it own economic strategy in response to price change to reflect on economic policy instead of following some other country trends.
\end{abstract}

(C) 2020 The authors, under a Creative Commons Attribution-

NonCommercial 4.0

Corresponding author's email address: mriaz@gudgk.edu.pk

Recommended citation: Riaz, M., Rahman, S., Mushtaq, S. and Atta, A. (2020). Oil Price Flux and Macroeconomy of Oil Exporters. Journal of Accounting and Finance in Emerging Economies, 6(2), 651-667

\section{Introduction}

Oil is an imperative energy source and macroeconomic factor embodies the largest commodity market in the world that can cause direct as well as the indirect effect on economic activity. Oil prices and global economic performance is highly correlated (EIA) ${ }^{1}$. Inflationary pressure and inflationary shocks stem from oil prices mostly if there exist no closer substitute of oil energy. (Brown and Yucel 2002; Cologni and Manera ; LeBlanc and Chinn 2004)

Oil Exporter and Importers both has absurd drive due to oil price fluctuations. Generally, a rise of oil prices has positive impact on exporters in reference to wealth anthology because of swing in terms of trade that depends on the elasticity of oil demand. Moreover, Oil encompassing the major GDP share as a source of earnings in oil exporting

\footnotetext{
${ }^{1}$ Energy information Associations (EIA)
} 
countries and source of spending in importing countries. Therefore, oil price fluctuation affects almost all the countries through different channels of macroeconomic variables. However, these macroeconomic changes take place with dissimilar degrees among countries having different economic features (Peersman and Van Robays 2012).

Throughout the history, Oil market has been in oscillation. Several factors including economic (e.g. high growth followed by high demand), non-economics (e.g. political motivation) and unanticipated economic development can be attributed to price volatility. An upward swing in prices act as a tax on consumption, leads to affect the cost of production, output, and employment negatively that causes inflation and another economic bug as suggested by a classical economist. However, downward swing in prices does not act in opposite showing price volatility have an asymmetric effect (Nusair, 2015).

Since few years, the fluctuating oil prices have attracted the attention of researchers, specifically in reference to the economic developments and macroeconomic policy issues. Because oil revenues and losses both are huge that can cause a significant impact on economic growth, inflation, current account balances and many other variables. Revenues and losses from Oil in oil-dependent economies are volatile and exhaustible because of uncertain external demand and supply of Oil. These fastidious features of oil operation mark on the challenges for economic planning in long run in terms of fiscal sustainability, as well as in the short run with regard to macroeconomic stabilization. Over the decades, macroeconomic developments in oil dependent economies are generally unfavorable, owing to oil price fluctuations characterized by dwindling economic growth, current account, and fiscal balances. Moreover, biggest challenge in the majority of countries in recent years is inflationary pressure come forward due to oil prices turn over. Unfortunately, established exchange rate regimes either fixed peg or tightly managed floats has constrained the monetary policy in tackling these challenges ( Bilgin et al., 2015). This has left a gap for the researcher to establish a policy to carry the main burden of macroeconomic stabilization.

To evaluate the relationship between economic variables and oil prices, short run as well as long run, impulse response and Vector Auto Regressive model(VAR) is applied in the study.Oil prices, consumer price index, GDP deflator, lending interest rate, real interest rate, exchange rate, and domestic credit has been analyzed to insight the appropriate policy according to the cause and effect relationship between price and these variables.

The analysis of oil prices upshot on the economic variables helps to locate the sensitivity of economic variables to oil price change. The relationship among variables facilitates to find the direction of policy implications that also signal which variable should be focused more in which particular direction for economic stability.

\section{Methodology}

With reference to research objective defined, the quantitative method approach is materialized. That is based on, Johansen Co-integration Technique and Error Correction Mechanism (ECM). This study used the time series data covering the time period from 1970 to 2019 for 10 largest oil exporting countries of the world to analyze the behavior of the economic variables in response to oil price change. In order to examine the oil price change and its dimensions in reference to the economic variables, we start with the traditional supply-demand function.

\section{$Y=f(p)$ Considering the other things constant}

(Equation 1)

Where $\mathrm{Y}$ is the output/supply of oil in a country, $\mathrm{p}$ is price level; there exist a positive relationship between price and supply, a rise in oil price drive an increase in supply, while oil price lessening grounds a reduction in supply. Increase in price level gives a push to production and other variables in the economy where the spillover effect on growth is also expected. However, if the economy is at full employment level then this push in high price will increase the inflationary pressure only. Therefore, variables chosen in the study are assumed in reference to the monetary phenomenon (inflation (family) construct).

\section{Variables and Data}

The aim of the study was to find the impact of oil price change on the economic variables of the economy and dimension of the relationship among these variables. Reviewing the literature, economics variables that have been 
considered in this study are:- Oil Prices (OP), Inflation taken as consumer price index on the basis of annual percentage increase (CPI), Inflation taken as annual percentage increase GDP deflator, Lending interest rate, real interest rate, Official exchange rate, and Net domestic credit. All the variables selected for the study are fundamental component of the monetary phenomenon.

Oil Price $(O P)$

Oil price was taken in US dollar per barrel from 1970 to 2019

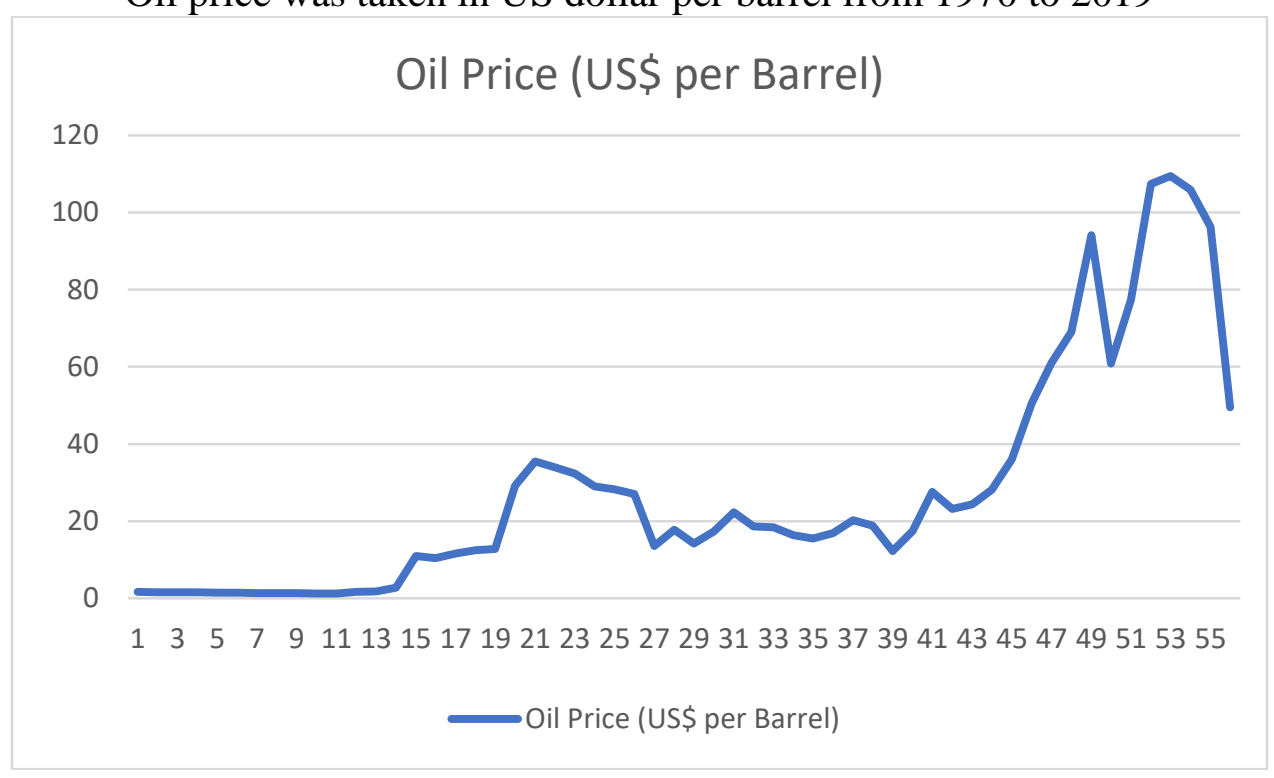

The prices of oil are showing increasing trend in initial years but at slow move. The price was highest at the end of series and suddenly showing a downward trend that indicates that oil prices bubble burst in last decade afterwards prices start declining. In previous few years back OP start rising yet again stroked the lowest level in 2019-2020 due to Corona Virus Pandemic. That slowed down all economic activities. Throughout the history, oil prices remained unstable and unpredictable. Therefore, the effect of oil prices on the economy and macroeconomic variables is not only unpredictable but also inevitable.

\subsection{Inflation (CPI)}

A basket of commodities and services predetermined or adjustable at specified intervals illustrates the annual percentage change in the cost of living of typical consumer, is calculated by the consumer price Index. Laspeyres Index is applied as the rule of measurement for CPI. The ultimate effect of an increase in oil prices leads to cost of production increase that deposit in consumer price index. CPI is taken to analyze the effect of oil price change on living standard of consumer as the expected relationship between both variable is positive.

\subsection{GDP deflator (GDPD)}

The annual growth rate of price change as a whole for the economy is reflected by GDP deflator, a measure of the level of prices of all new, nationally manufactured, final goods and services. Annual growth rate is the ratio of GDP in current local currency to GDP in constant local currency. It is an economic measurement that considers inflation by changing the prices from current to constant base year's GDP. It is a more reliable measure to depict the inflated price level in the economy over a specified time period. The expected relationship between OP and GDPD is positive.

\subsection{Lending Interest Rate (IR)}

To accommodate the short and medium term financing demands of the private sector the funds are provided for a price named as the lending interest rate. The rate is designed according to the objectives, conditions, and creditworthiness of the customers in different countries. This variable is important to reflect the economic activity of the economy. It is expected that more IR less economic activity and vice versa. Hence a negative relationship is expected between OP and IR in oil exporters. Higher Oil Prices leads to aggregation of more wealth and more funds available at lower IR. 


\subsection{Real Interest Rate (RIR)}

Real interest rate is the inflation adjusted rate. Real interest rate depicts the real increase in purchasing power hence it is more reliable to measure the change in production and consumption behavior of the economy. Fisher equation described the rate more formally stating that the real interest rate is indisputable as it is obtained as the nominal interest rate minus the inflation rate.

\subsection{Exchange Rate (EX)}

Exchange rate determines the value of the domestic currency in reference to foreign currency. It is determined by the national authorities or in the legally authorized exchange market. The exchange rate is important in the globalized world because all trade or movement of capital is conditional on the exchange rate of a currency. Stable economy and stable exchange rate depicts the effective fiscal and monetary policies. It is calculated on yearly average based on monthly averages (native currency units compare to the U.S. dollar mostly). Oil Exporter may have expected positive/negative relationship among OP and EX depending on share in export market.

\subsection{Local Domestic credit (LDC)}

The amount of credit provided to borrowers by the country or territory's central Bank within the same territory is referred as domestic credit. Commercial banks and even the government itself may involve in it. Furthermore, bank loans and government borrowed money to finance its budgetary support activities included in domestic credit expansion. Growth in the total amount of money in a country's economy at a specific time is measured by LDC.

\section{Estimation Procedure}

Since the data set consists of time series, hence Johansen Co-integration Technique is used to determine whether a long run relationship exists between the variables in question. This technique requires the same order of stationarity among the time series of variables to find the empirical estimates. Therefore, the stationarity of the variable is checked and their order of integration is found first. Then the Johansen Co-integration test is used to find the long run relation. Whereas, Error Correction Model technique is used to find the short run relationship. Our data set has unit root hence the ordinary least square method was expected to yield the biased results. In the same way, autoregressive lag distribution model was not suitable because the data series were stationary at same level. Hence, the Johansen integration was the best model for our data due to data characteristics.

\subsection{The Johansen Co-integration Technique}

Co-integration technique ensures that the long run relationship has a meaning. If the variables data series depicts different trends than long run relationship doesn't exist. In that case co-integration technique cannot be used to determine the long run relationship. Johansen (1995) test is preferred due to its superior methodology nonetheless it has its weakness as well such as it requires large data sample. Johansen test requires the order of the integration to be 1 for the entire data set.Augmented Dicky Fuller (ADF) test is used to identify the order of integration.

\subsection{ADF Test}

$\mathrm{ADF}$ technique is used to unit root testing and to confirm the stationarity of the series. Below is the equation of ADF $\Delta y_{t}=\alpha+\beta t+\gamma y_{t-1}+\sum_{i=1}^{p-1} \Delta \delta_{i} y_{t-p+1}+\varepsilon_{t}$

where $\alpha$ is a constant, $\beta$ the coefficient on a time trend and $p$ is the lag order of the autoregressive process. In order to check the order of autoregressive process, the lag length $p$ must be defined.

Ho: unit root exists

H1: unit root does not exist.

The p-value of the ADF test determines the status of the null to be rejected or not. If the p-value is less than 0.05 we reject the null and concluded the series are stationary. However, if p-value is greater than 0.05 we will accept the null that series are not stationary and has a unit root.In case of unit root, first difference of data series will be checked for 
stationarity and so on. Once the order of integration is found we move on to applying Johansen Co-Integration test.

\subsection{Johansen Co-integration Test}

Test allows more than one co-integration equations. The following equation is the basic equation of the co-integration test.

\section{$Z_{t}=\sum_{i=1}^{k} A_{i} Z_{t-i}+\varepsilon_{t}$}

Where $\mathrm{Zt}$ is the vector of the variables which are to be estimated appearing as independent and dependent variables. Since the test allows only 1 order of integration, $\mathrm{Zt}$ variables must be estimated at a level.

$\Delta Z_{t}=\pi Z_{t-i}+\sum_{i=1}^{k-1} \theta_{i} \Delta Z_{t-i}+\varepsilon_{t} \ldots \ldots \ldots$

Then as per the Granger Representation Theorem

- If-rank $(\pi)=$ number of variables in VAR, then $\mathrm{Z}_{\mathrm{t}}$ includes all stationary variables

- If $\operatorname{rank}(\boldsymbol{\pi})<\mathrm{n}$ then there exists a representation of $\boldsymbol{\pi}$ such that $\boldsymbol{\pi}=\boldsymbol{\alpha} \boldsymbol{\beta}^{\prime}$

Where $\alpha=$ adjustment matrix and $\boldsymbol{\beta}^{\prime}=$ cointegration matrix

Where $\alpha$ and $\beta$ are matrices with dimensions $\mathrm{n} \times \mathrm{r}$ and each column of matrix $\alpha$ contains coefficients that represent the speed of adjustment to disequilibrium, while matrix $\beta$ contains the long-run coefficients of the co-integrating relationships.

The rank of a matrix (r) being defined as the number of linearly independent rows, Johansen derived two tests, the $\lambda-\max$ (or maximum eigen value test) and the trace test. The Johansen max test is constructed as

$\lambda_{\text {trace }}(r)=-T \sum_{i=r+1}^{n} \ln \left(1-\lambda^{\wedge}{ }_{\text {trace }}\right)$

Ho: the number of co-integrating vectors (is less than or equal to) $\leq r$, no cointegration exists.

$\mathrm{H}_{1}$ : unspecified

$\lambda_{\max }(r)=-T \ln \left(1-\lambda^{\wedge}{ }_{r+1}\right)$

Ho: the number of co-integrating vectors is $=r$

$\mathrm{H}_{1}$ : the number of co-integrating vectors is $=\mathbf{r}+1$

Generally, $\lambda$-max and $\lambda$-trace statistics are sensitive to under parameterization of the lag length. However, the trace test is the better test, since it occurs to be more robust to skewness and excess kurtosis. Furthermore, the trace test can be adjusted for degrees of freedom, which can be of importance in small samples.

\subsection{Error Correction Model (ECM)}

In order to find the short-run relationship between the variables, ECM model is used. When data series move together over time, standard OLS technique yield spurious regressions. To get over the problem ECM estimates the long-term relationship among the variables, while allowing for the short run deviations from this long run relationship.

$\Delta Y_{t}=\alpha+\beta_{0} \Delta X_{t}+\gamma E C M_{t-1}+\mu_{t}$

Given (A) presents the general form of ECM equation. $X_{t}$ and $Y_{t}$ represent a long run relationship where short run relationship is affected by the presence of the ECM. Here the error term of the long run relationship is introduced in order to avoid the spurious regression in short term.

$\Delta Y_{t}=\alpha+\beta_{0} \Delta X_{t}+\gamma E C M_{t-1}+\mu_{t}$

This model provides both short run and long-run elasticities, moreover, it is consistent in dealing with data which contains the unit root problems. From ECM, the impulse response can also be generated.

\section{Result and Analysis}

Data has been taken for major oil exporter to analyze the relationship of oil prices with other economic variables. Data is time series for 10 major oil exporters. Time period started from 1970 and ended at 2019 so that maximum number 
of values can be included in the analysis. Countries included were Saudi Arabia, Russia, Iran, Iraq, Nigeria, UAE, Angola, Kuwait, Venezuela, and Canada, based on their major percentage share in oil export (CIA world fact book). Variables taken from World Development Index (WDI) are price of crude oil (OP), Real Interest Rates (RIR), Consumer Price Index (CPI), GDP deflator (GDPD), Official Exchange rate (EX) and Domestic Credit Unit (LDC) and lending interest rate (IR). The unit root test, Vector Error Correction Mechanism, Normality test for data and cointegration result are explained.

\subsection{Unit Root Test}

ADF test is used to find the unit root for all data series in the model to avoid spurious relationship between the variables. Data series has unit root/ meaning that data is not stationary checked against the alternative hypothesis means data has no unit root/ data is stationary. The following table shows the results of the unit root tests.

Table I - ADF Test

Variable At level At difference

\begin{tabular}{cccccc}
\hline Name & ADF stats & Probability & ADF stats & Probability & Level of Integration \\
OP & -1.362123 & 0.8579 & -5.179506 & 0.0001 & $\mathrm{I}(1)$ \\
\hline GDPD & -2.133192 & 0.5115 & -3.442894 & 0.0148 & $\mathrm{I}(1)$ \\
\hline CPI & -1.787440 & 0.6934 & -6.348143 & 0.0000 & $\mathrm{I}(1)$ \\
RIR & -1.585983 & 0.7821 & -6.024158 & 0.0000 & $\mathrm{I}(1)$ \\
\hline EX & -3.148741 & 0.1085 & -8.103892 & 0.0000 & $\mathrm{I}(1)$ \\
\hline LCU & -1.348851 & 0.8617 & -5.574062 & 0.0001 & $\mathrm{I}(1)$ \\
\hline
\end{tabular}

The Table-I display that all variables in the study were non-stationary at the level 0.05 confidence level. While, checking the stationarity after first difference all the variables become stationary at 0.05 level of confidence. The pvalue of the variables is higher than 0.05 hence accepting the null hypothesis stating that the variables have a unit root at level. Since all the variables are stationary at first level difference, or in other words I (1), Johansen Co-integration Technique is appropriate.

\subsection{Empirical Analysis}

To find the long run relationship Co-integration test was applied to the variables. To find the integrating equations among variables Trace Stat and Maximum Eigen values Stat are used. The null hypothesis states that no cointegrating equations exist between the variables. From the Trace and Max-Eigen test, it was determined how much co-integrating equations exist in the system. 


\section{Trace test}

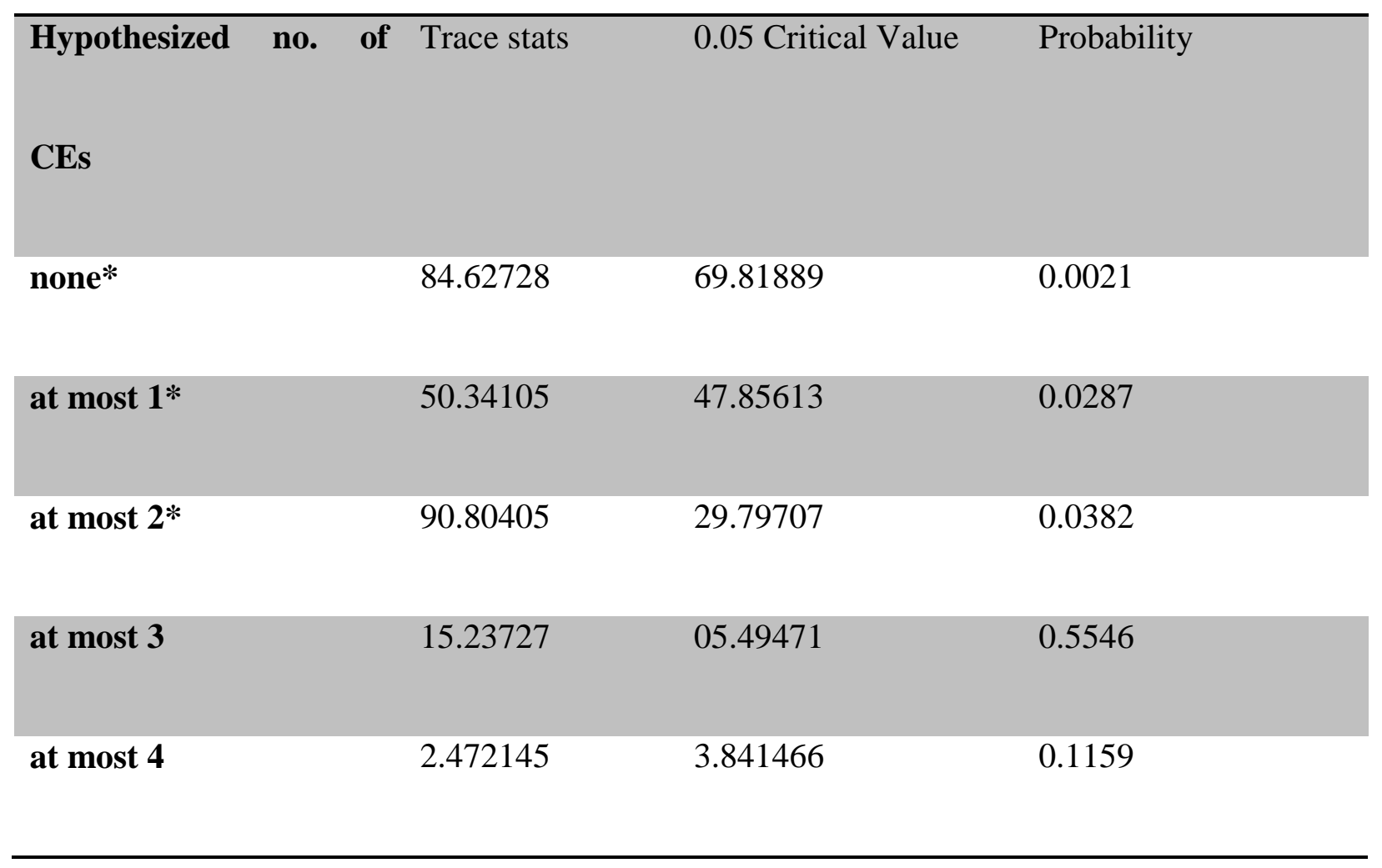

Trace test rejects the null of hypothesized number of Co-integrating equations at none, 1 , and 2 . While at most 3 , the study accepts the null stating that there are 3 co-integrating equations which exist at 0.05 percent level of confidence.

\section{Maximum Eigen Value}

\begin{tabular}{|c|c|c|c|}
\hline $\begin{array}{l}\text { Hypothesized no. of } \\
\text { CEs }\end{array}$ & Max Eigen stats & 0.05 Critical Value & Probability \\
\hline none* & 34.28624 & 33.87687 & 0.044 \\
\hline at most $1^{*}$ & 19.53700 & 27.58434 & 0.032 \\
\hline at most $2^{*}$ & 15.56678 & 21.13162 & 0.012 \\
\hline at most 3 & 12.76512 & 4.264600 & 0.185 \\
\hline
\end{tabular}




\begin{tabular}{llll}
\hline at most 4 & 2.472145 & 3.841466 & 0.115
\end{tabular}

Maximum Eigen Value test rejects the null of hypothesized number of Co-integrating equations at none, at most 1, and at most 2. We accept the null indicating that there is 3 Co-integrating equation. Both Trace and Max Eigen Value Statistic indicate that there is at most three Co-integrating relationships in the system among variables. Hence as the variables are co-integrated, we can apply vector error correction model (ECM) to analyze the relationship. Table A.1 in the appendix shows the estimated co-integrated vectors and vector error correction model (VEC) ${ }^{2}$.

Table-II Long run Results

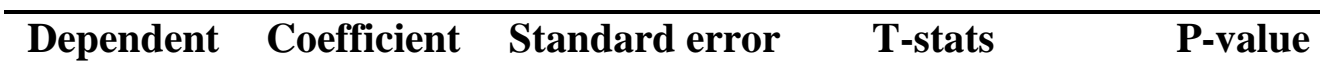

Variable

CPI

\begin{tabular}{lllll}
\hline RIR & 4.16 & 0.29 & 14.26 & 0.000 \\
DC & -3.79 & 0.08 & 0.472 & 0.1403
\end{tabular}

\begin{tabular}{ccccc} 
EX & -0.058 & 0.016 & 3.60 & 0.022 \\
\hline OP & -0.126 & 0.153 & 0.82 & 0.002 \\
\hline
\end{tabular}

Note: At 0.05 level of confidence

The estimates of ECM model showed the Co-integrating vectors. From results, the long rum relation can be written as in equation form as:

$\mathrm{CPI}=36.18-4.16 \mathrm{RIR}+3.79 \mathrm{DC}+0.058 \mathrm{EX}+0.126 \mathrm{OP}$

This is normalization equation that is estimating the relationship between CPI in reference to OP and other variables as independent. Under this normalization, oil price has a significant effect on CPI in the long run as this is significant. Similarly, RIR and EX have a significant effect on CPI. LDC has insignificant relation with CPI in our data set.

\footnotetext{
${ }^{2}$ To simplify the results, one of the co-integrating (CE) results for IR is not reported in the study, as the results is insignificant for OP.
} 658 


\section{Long run results}

\section{Dependent Variable: GDPD}

\begin{tabular}{ccccc}
\hline Variables & Coefficients & Standard error & T-stats & P-value \\
\hline RIR & 5.36 & 0.37 & 14.33 & 0.000 \\
\hline DC & 2.90 & 0.10 & 0.27 & 0.231 \\
EX & -0.075 & 0.020 & -3.63 & 0.024 \\
OP & -0.133 & 0.198 & -0.66 & 0.003 \\
\hline
\end{tabular}

The long-run relation in the equation form is written as:

GDPD=43.48-5.36(RIR)-2.90(LCU) +0.075(EX) +0.133(OP)

Under this normalization equation OP, RIR and EX have a significant relationship with GDPD whereas LDC is insignificant.

In the above ECM there exist 4 common stochastic trends that are RIR, DC, EX, and OP whereas CPI and GDPD linearly related to these stochastic trends in long run. ECM Estimates are shown in Appendix Table A.2 that also shows: C (1) is the error correction term. When the C (1) is negative in coefficient and significant, it can be said that there is a long run causality running from independent variables towards dependent variable. It also indicates the speed of adjustment towards long-run equilibrium.

In the ECM estimates, the first co-integrating equation indicates that CPI, GDPD, RIR, LCU, and EX are statistically significant which are sole equilibrating factors in the short run. In the second and third equilibrating equation, all the variables CPI, GDPD, RIR, LDC, and EX are equilibrating factors in the short run whereas OP is insignificant in all equations that shows it is not equilibrating factor in any relationship.

\section{Robustness of the model}

\begin{tabular}{ll}
\hline Test & P-value \\
\hline Jarque Bera: Normality test & 0.7474
\end{tabular}




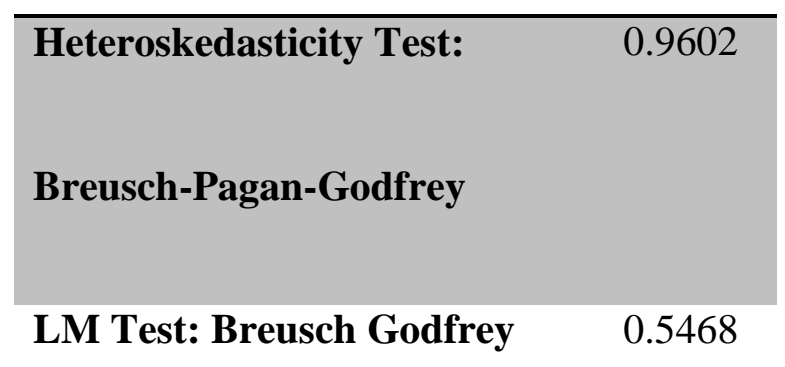

\section{Serial Correlation}

Note: at 0.05 confidence interval

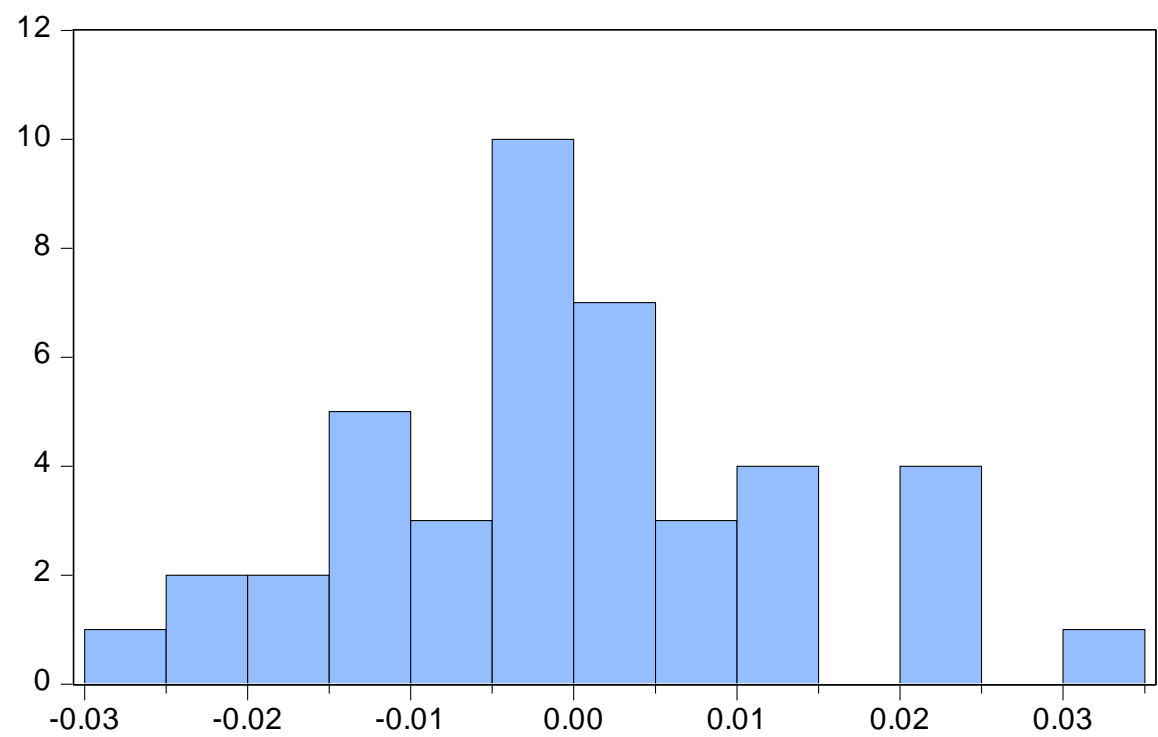

\begin{tabular}{|lc|}
\hline & \\
Mean & $-1.86 \mathrm{e}-18$ \\
Median & -0.001372 \\
Maximum & 0.032334 \\
Minimum & -0.027795 \\
Std. Dev. & 0.013362 \\
Skewness & 0.283513 \\
Kurtosis & 2.894579 \\
& \\
Jarque-Bera & 0.582107 \\
Probability & 0.747476 \\
\hline
\end{tabular}

The above table shows the test summary of the model estimated. As the results indicate there is no problem of normality, heteroskedasticity and serial correlation. The normality test which follows the Chi-square distribution has the p-value of 0.7474 which is higher than 0.05 so we accept the null hypothesis. There is no problem of normality in the system. The heteroskedasticity test follows the F distribution and has the p-value of 0.9602 which is greater than 0.05, so we accept the null hypothesis of homoscedasticity. The LM test follows the Chi-square distribution and has the p-value of 0.5468 which is greater than 0.05 , so we accept the null hypothesis of no serial co-relation. The CUSUM Test is estimated to perform a cumulative test for randomness. 

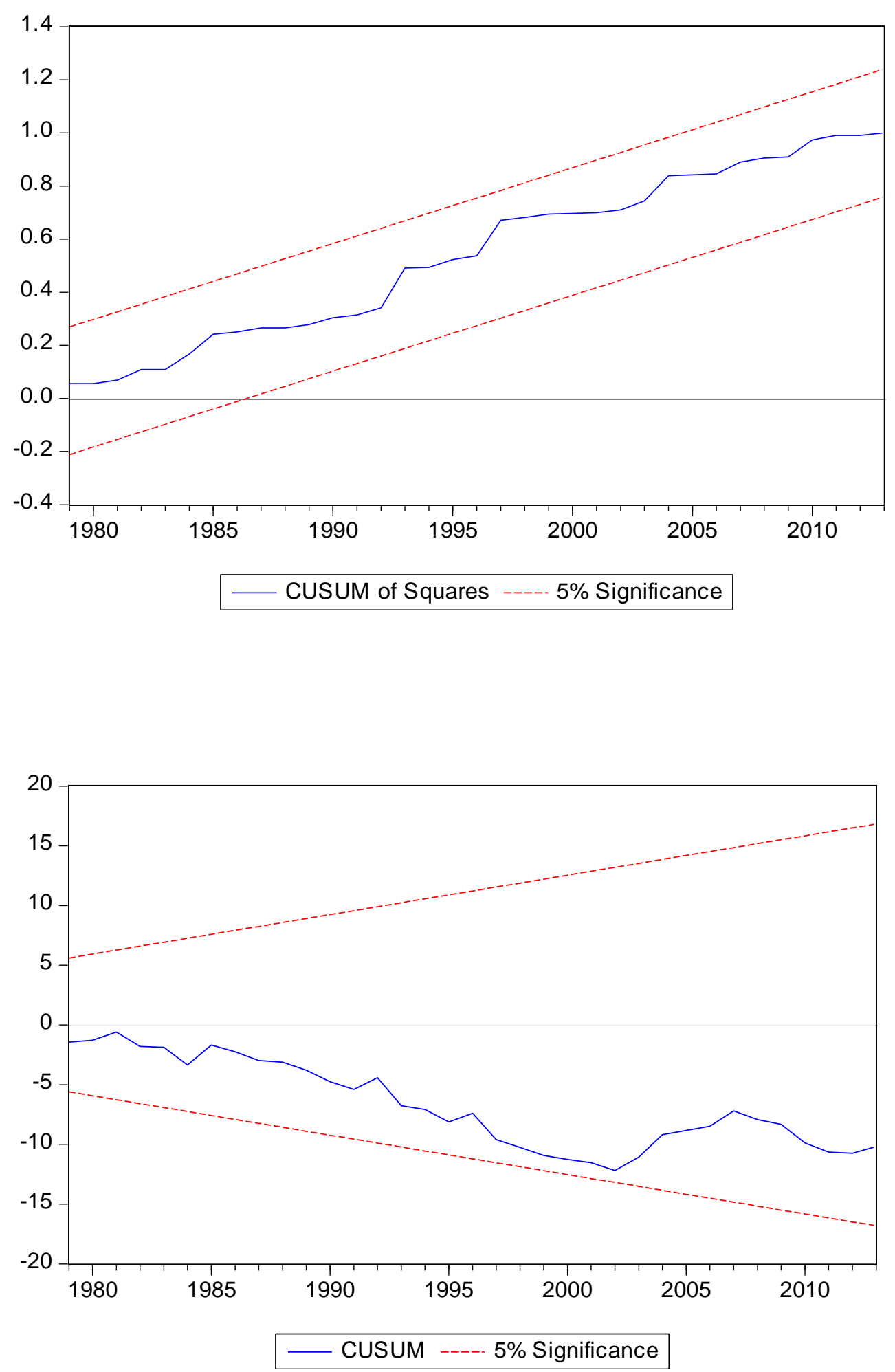

The CUSUM and CUSUM square lies within the band of 5 percent significance indicating that the model is robust. Short Run Relationship

To analyze the relationship between variables, the variance decomposition is applied. The method shows that when a shock is given to a variable, how it transfers to the other co-integrating variables. Hence to analyse, the shock is given to different variables in the model, variance decomposition ${ }^{3}$ results are given in the Tables A.3.

${ }^{3}$ Only for oil price is reported. 
The Table in appendix A.3 shows the 10-period effect of an oil price shock on economic variables taken in the study. The decomposition shows the shock of oil prices affect the GDPD and RIR more as compared to other variables in the model. The effect in short run is less than the long run. In long run, Inflation factors changes more due to OP. Hence it is inferred that oil price effect penetrates in the economy with the passing of time and eventually it is evidenced from GDPD (measure of inflation) in the economy. To analyses the same effect, the impulse response is given in Figure I.
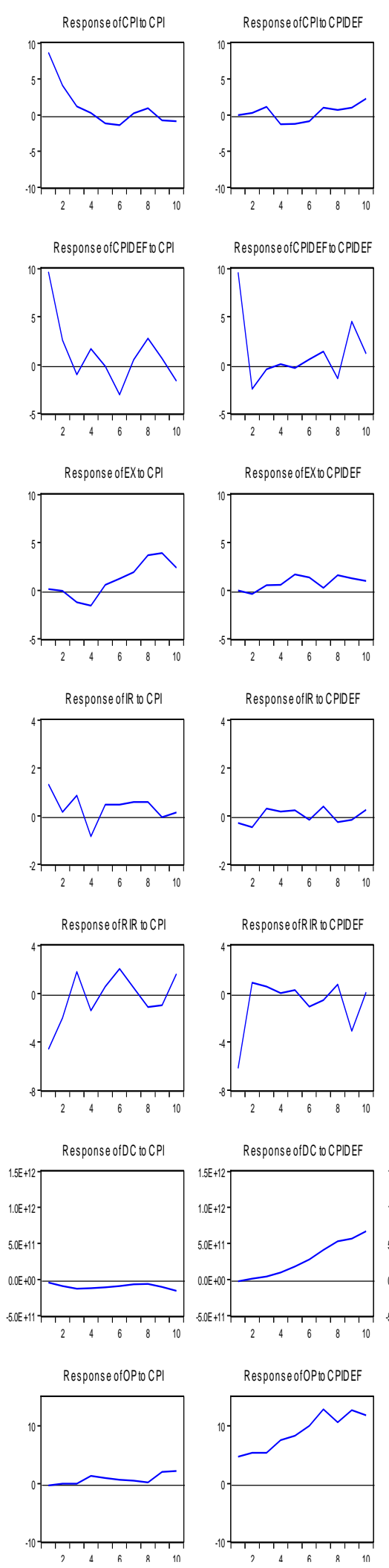
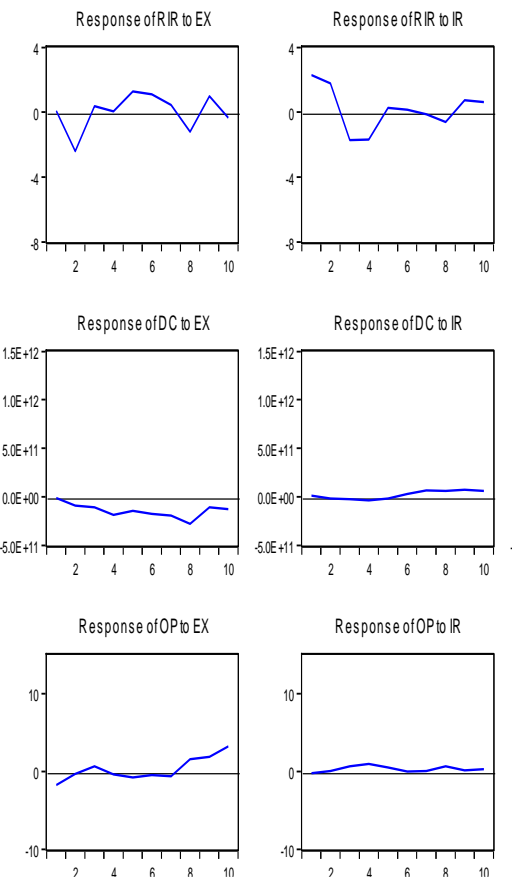
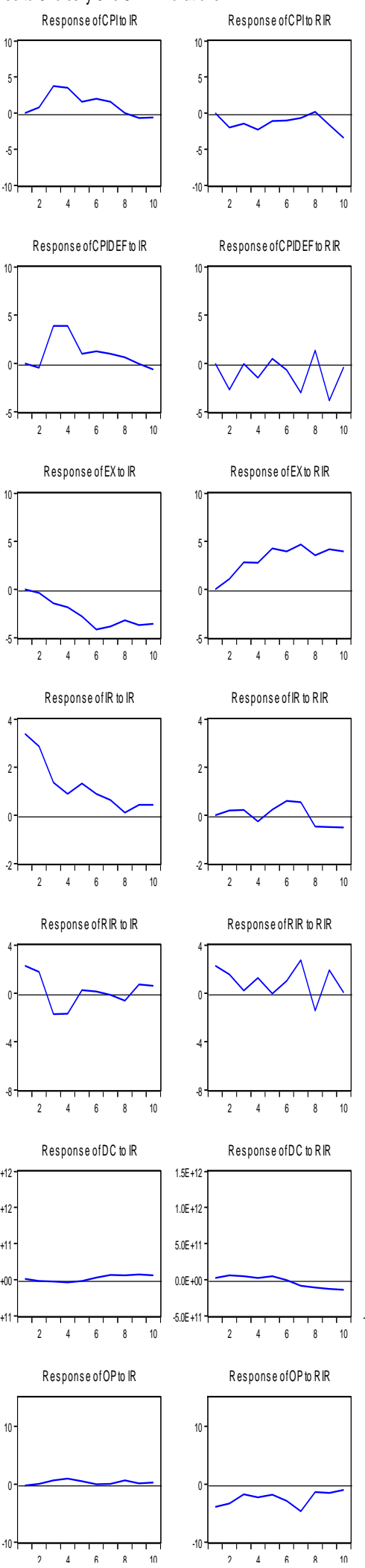
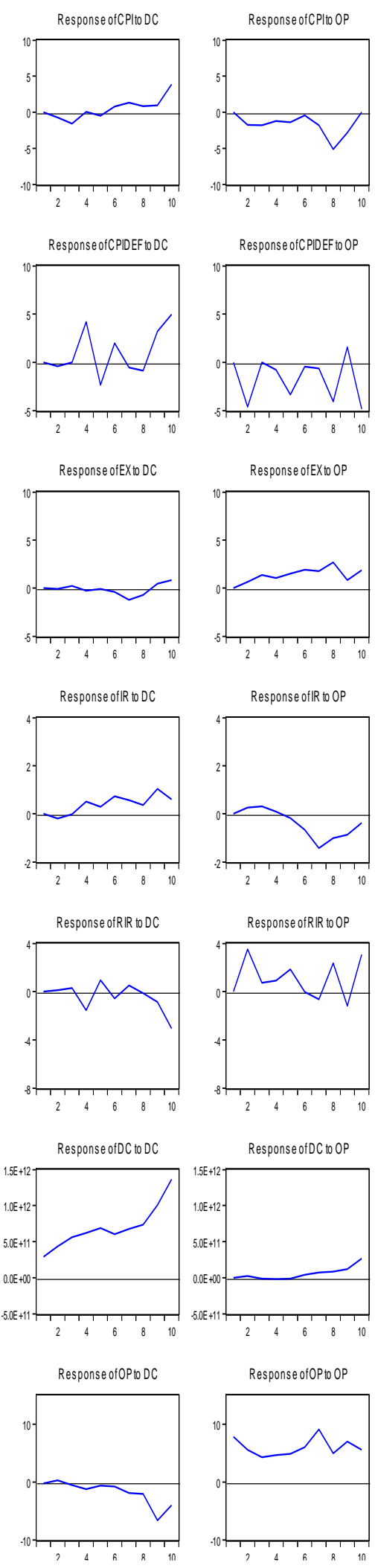
The figure shows, on the whole, oil prices changes in the oil exporting country effect more on its CPI and interest rate as compared to other economic variables. These effects are adjustable and the economy shows a tendency to revert back to its equilibrium.

\section{Discussions}

The main objective of the study was to examine the relationship of leading economic variables of major oil exporting countries in reference to oil price changes. Oil is the primary earning source of many oil exporting countries. The countries that are exclusively dependent on oil export represent more effect on their export shares and earning income in response to oil price changes, that further cause a spillover effect on other variables of the economy either in short run or in long run. Though all the economies are influenced from oil changes either directly or indirectly, yet, the magnitude of response is different and unpredictable always. Different variables respond to oil price change in different ways and through different channels. These channels are linked to the government policies directly or indirectly.

The study found that CPI and GDPD are related to, RIR, EX and OP significantly exhibiting their adjusted behavior in response to change in these variables. Oil price is significant in all long-run estimated equation displaying the oil price relationship with CPI, GDPD. The literature showed that almost every second study included CPI and OP in their analysis because of their close association and CPI is main component of oil price (hikes) fluctuations. Several studies: for instance, Hooker (2002) revealed the significant association between oil prices and inflation, suggesting the oil price impact on CPI is very strong. Castillo et al. (2010) also discovered that rising volatility in the price of the oil could lead to more inflation. Similarly, Kormilitsina (2011) studied the oil price volatility effect on inflation and interest rates and found both increased with the price increase. However, the work of Chou and Tseng (2011) was found contradictory that analyzed the spiral effects of oil prices on CPI inflation among the category of developing Asian countries.

Monetary Policy tool of action is interest rate; a crucial instrument. Several studies focus on the the interest rate response to oil price fluctuation through the channel of monetary policy. A number of studies have reflected the direct channels of oil price transmission ( Barsky and Kilian; 2002). Empirical studies demonstrated that to compete with the inflation due to unanticipated oil price fluctuations, contractionary monetary policy is advocated that increase the interest rates, the upward movements in interest rates are transmitted to the real economy by minimizing the output growth and the rate of inflation. (Smetsand Peersman, 2001 and Tillmann, 2008). In our analysis, RIR and OP are significantly related as shown by other studies too.

The exchange rate movements in response to oil price changes are studied by a strand of researchers. As a matter of fact, Rogoff (1991) recognized the effect of high oil prices on export competition and price level.That gave rise to continual and indefinite change in exchange rate. For instance, in studies by Aloui( 2013), Ding and Vo, (2012) and $\mathrm{Wu}$, (2012), it was discovered that the increase in oil price is directly related to the appreciation of the dollar. Contrary to this, other studies demonstrated a negative association between oil prices and the exchange rates of the U.S. dollar (Narayan et al., 2008 and Zhang et al., 2008). Buetzer et al. (2012) showed that there was no indication of the systematic increase of net oil exporter's exchange rate due to oil price change. Similarly, Dauvin (2014) approximates panel smooth transition regression models for 10 energy-exporting countries but did not recognize a clear relationship between positive terms of trade shocks and the real exchange rate appreciation for oil-exporting countries with the exception of Venezuela. There are many other studies that analyzed the relationship of oil price change with the exchange rate and found unusual results. In our analysis there exist no direct long run relationship between OP and EX as both are stochastic trends in our results. OP showed its long run association with inflation only either it measured by CPI or GDPD.

The results of our study demonstrated that oil price and economic variables are positively related. An increase in the price of oil effect the consumer prices and interest rate positively that indicated an inflow of credit in the oil exporting countries (Reference Table 4.4). The inter-linkage of economic variables affects each other through different channels that ultimately cause the inflation and interest rate to increase. 
In order to analyze the short run relationship among variables variance decomposition and impulse response has been calculated through ECM. It was found that oil price change has a positive effect on all economic variables but these effects were getting strong with the time. For 10 lags of a variable, it is seen that oil price effect is less at the start but getting bigger in magnitude at the end. Hence, it can be deduced that oil price shows its effect on the economy gradually. The oil price has a stronger effect in 10 period lag for GDPD and RIR as compared to other variables.

In order to analyze the short run relationship among variables; The impulse response is also taken in the study. Focusing only on the response of variables to oil price, it can be seen that the effect until 10 lag is visible and this effect of oil price on an economic variable is out of print. The similar results are seen in the literature (Ahmed. A. and Wadud, 2011, Rahman and Serletis, 2010),Moreover, an enormous collection of literature recognized oil price shocks following the Cholesky factorization, where oil prices are made to influence all the other macroeconomic variables contemporaneously (Blanchard and Gali, 2007; Burbidge and Harrison, 1984 and Leduc and Sill, 2004).

Hence it is deduced that all variables are showing their fluctuations in response to oil price change in the short run. Oil shocks were significant for short-run economic development for the reason that their capacity to upset purchases of large production and investment of goods (Bernanke, 1983). Bernanke (1983) and Hendry (1995) proposed theory of investment under uncertainty was the postulate upon the argument on oil price ambiguity and its impact on macroeconomic variables.

\section{Conclusion}

Oil price fluctuation has usually different but positive effect on the economic variables that demonstrated, being an important energy source initial shock or change in prices effect all the economies yet magnitude of oil shocks depends on the share of oil production in the overall energy production in the country as well as on the share in the national income. The result of the study has confirmed previous researches, however, oil price shocks have shown smaller effect on the economies under consideration in comparison to earlier studies due to government attention towards other energy sources and on the development of alternative sources to grow the earning of the countries.

Earlier Studies showed several channels through which oil price hikes affect the economies including the transfer of wealth from oil consumers to oil producers, an increase in the cost of production of goods, the effect on consumer confidence, impact on inflation, policy adjustment and financial markets. This study showed that though the economy of oil exporting countries has a positive relationship with the price change yet this impact is not long lasting. In the long run, economy reverts back to its equilibrium and in the short run effect is only significant for consumer price index and interest rate as compared to other economic variables. This is because the price volatility affects the consumer trust and augments the investment uncertainty due to which CPI and Interest rate relationship with oil prices is more prominent as compared to other variables. Hence, government and policy makers should control the price hikes by focusing on the money supply in the countries.

It is important to mention that study has taken only a few economic variables to analyze the effect on economy, therefore, results are limited, including more variables and more channels, more fruitful results are expected to obtain in future research. 


\section{References}

Ahmed. A. and Wadud ( 2011), Role of oil price shocks on macroeconomic activities: an SVAR approach to the Malaysian economy and monetary responses. Energy Policy 2011; 39:8062

Barsky and Kilian(2002), Barsky RB, Kilian L. Do we really know that oil caused the great stagflation? A monetary alternative. NBER Macroecon Ann 2001; 2002(16):137e98.

Bernanke, B. S. (1983). Irreversibility, uncertainty, and cyclical investment. The Quarterly Journal of Economics 98 (1), 85-106.

Bernanke, B., J. Boivin, and P. S. Eliasz (2005). Measuring the effects of monetary policy: A factor-augmented vector autoregressive (favar) approach. The Quarterly Journal of Economics 120 (1), 387-422.

Bernanke et al (1997), Bernanke, B. S. and I. Mihov (1998). Measuring monetary policy. The Quarterly Journal of Economics 113 (3), pp. 869-902.

Blanchard, O.J., Gali, J., (2010). The macroeconomic effects of oil shocks: why are the 2000s so different fromthe 1970s? In: Gali, J., Gertler, M. (Eds.). International Dimensions of Monetary Policy. University of Chicago Press, pp. 373-428

Brown and Yucel 2002; Brown, S.P.A., Yücel, M.K., 2002. Energy prices and aggregate economic activity: an interpretative survey. Q. Rev. Econ. Finance 42, 193-20

Buetzer et al. (2012) Buetzer, S., Habib, M.M., Stracca, L., 2012. Global exchange rate configurations. Do Oil Shocks Matter?. ECB Working Paper Series, no 1442 (June)

Cologni and Manera 2008. Cologni A, Manera M. Oil prices, inflation and interest rates in a structural cointegrated VAR model for the G-7 countries. Energy Econ 2008; 30:856e88.

Dauvin (2014) Dauvin, M., 2014. Energy prices and the real exchange rate of commodity-exporting countries. Int. Econ. 137, 52-72

Gisser and Goodwin 1986; Gisser, M., \& Goodwin, T. H. (1986). Crude oil and the macroeconomy: Tests of some popular notions: Note. Journal of Money, Credit and Banking, 18(1), 95-103.

Hamilton 1983, 1985; Hamilton JD. (1983) Oil and the macro economy since World War II. J Political Econ 1983;91:228e48.

Hendry (1974) Hendry, D.F. 1995. Dynamic Econometrics. Oxford University Press, Oxford (United Kingdom).

Hooker 1996; and 2002 ,Hooker, M.A. (2002), "Are oil shocks inflationary? Asymmetric and non-linear specifications versus changes in regime", Journal of Money, Credit and Banking, Vol. 34 No. 2, pp. 540-61.

Huang et al. 205; Huang WH, Chao MC. The effects of oil prices on the price indices in Taiwan: international or domestic oil prices matter? Energy Policy 2012;45:73.

Kormilitsina, A., 2011. Oil price shocks and the optimality of monetary policy. Rev. Econ. Dyn. 14 (1), $199-223$.

Krugman, P. (1980). Oil and the dollar. NBER Working Paper Series 554.

Lardic and Mignon 2006, 2008; Lardic, S., Mignon, V., 2008.Oil prices and economic activity: an asymmetric cointegration approach. Energy Econ.30, 847-855.

LeBlanc and Chinn 2004 LeBlanc, M., \& Chinn, M. D. (2004). Do high oil prices presage inflation? The evidence from G5 countries. Business Economics, 34(2), 38-48.

Leduc, S., Sill, K., 2004. A quantitative analysis of oil-price shocks, systematic monetary policy, and economic downturns. J. Monet. Econ. 51 (4), 781-808

Lee and Ni 2002; Lee, K., \& Ni, S. (2002). On the dynamic effects of oil price shock: A study using industry level data. Journal of Monetary Economics, 49(4), 823-852.

Lee, K., Ni, S., \& Ratti, R. A. (1995). Oil shocks and the macroeconomy: The role of price

variability. Energy Journal, 16(4), 39-56.

Mork 1989, 1994; Mork, K. A. (1994). Business cycles and the oil market. Energy Journal, 15(S), 15-38.

Narayan et al., 2008 Narayan PK, Narayan S. Modelling the impact of oil prices on Vietnam's stock prices. Appl Energy 2010;87:356e61.

Nusair, 2015) A. Nusair, S. 2015. The effects of oil price shocks on the economies of the Gulf Co-operation Council countries: Nonlinear analysis, Energy Policy 91(2016)256-267.

Peersman and Van Robays 2012; Peersman, G., \& Van Robays, I. (2012). Cross-country differences in the effects of oil shocks.

Energy Economics, 34(5), 1532-1547. 
Rahman and Serletis, 2010), Rahman S, Serletis A. The asymmetric effects of oil price and monetary policy shocks: a nonlinear VAR approach. Energy Econ 2010;32:1460e6.

Rogoff, K. (1991). Oil, productivity, government spending and the real yen-dollar

exchange rate: FRB of San Francisco, 1991. Working Papers 91-06.

Schimmel, W. (2008). Is the oil price being driven by a weak dollar? Vienna: Futures

Razmi et al (2016

Smets and Peersman, 2001 \&Smets, F.,Wouters, R., 2007. Shocks and frictions in US business cycles: a Bayesian DSGE approach. Am. Econ. Rev. 97 (3), 586-606.

Tang et al. 2010; Tang, W., Wu, L., \& Zhang, Z. (2010). Oil price shocks and their short and long-term effects on the Chinese economy. Energy Economics, 32(S1), 3-14.

Tillmann, 2008) Tillmann P. Do interest rates drive inflation dynamics? An analysis of the cost channel of monetary transmission. J Econ Dyn Control 2008;32:2723e44.

Wu, 2012, Wu,C.W.,Pearn,W.L.,Kotz,S.,2009.Anoverviewoftheoryandpracticeonprocess capability indicesforqualityassurance.Int.J.Prod.Econ.117(2),338-359.

Zhang et al., 2008). Zhang, Z., Lohr, L., Escalante, C. and Wetzstein, M. (2010), "Food versus fuel: what do prices tell us", Energy Policy, Vol. 38 No. 1, pp. 445-

\section{Appendix}

Table A.1

\begin{tabular}{|c|c|c|c|}
\hline & CointEq1 & CointEq2 & CointEq3 \\
\hline & & & \\
\hline CPI(-1) & 1.000000 & 0.000000 & 0.000000 \\
\hline GDPD(-1) & 0.000000 & 1.000000 & 0.000000 \\
\hline IR(-1) & 0.000000 & 0.000000 & 1.000000 \\
\hline RIR(-1) & 4.163606 & 5.368346 & 2.036260 \\
\hline & $(0.29184)$ & $(0.37740)$ & $(0.22168)$ \\
\hline & {$[14.2670]$} & {$[14.2245]$} & {$[9.18577]$} \\
\hline LCU(-1) & 3.79 & 2.90 & 7.93 \\
\hline & $(0.8)$ & $(0.1)$ & $(0.61)$ \\
\hline & {$[0.47278]$} & {$[0.27969]$} & {$[0.13028]$} \\
\hline EX(-1) & -0.057781 & $-\mathbf{0 . 0 7 5 3 6 7}$ & $-\mathbf{0 . 0 4 4 7 3 9}$ \\
\hline & $(0.01604)$ & $(0.02074)$ & $(0.01218)$ \\
\hline & {$[-3.60296]$} & {$[-3.63403]$} & {$[-3.67271]$} \\
\hline OP(-1) & -0.126759 & -0.133312 & $-\mathbf{0 . 1 1 2 6 4 1}$ \\
\hline & $(0.15387)$ & $(0.19898)$ & $(0.11687)$ \\
\hline & {$[-0.00823]$} & {$[-0.06699]$} & {$[-0.96378]$} \\
\hline C & $-\mathbf{3 6 . 1 8 4 9 0}$ & -43.48574 & -13.21702 \\
\hline & & & \\
\hline
\end{tabular}

Table A.2

\begin{tabular}{|c|c|c|c|c|c|c|c|}
\hline Error Correction: & $\mathbf{D}(\mathbf{C P I})$ & D(CPIDEF) & D(IR) & D(RIR) & $\mathbf{D}(\mathbf{D C})$ & $\mathbf{D}(\mathbf{E X})$ & $\mathbf{D}(\mathbf{O P})$ \\
\hline \multirow[t]{3}{*}{ CointEq1 } & -0.898669 & 0.812181 & 0.031206 & -0.288408 & -2.02 & -0.203797 & 0.030164 \\
\hline & $(0.13237)$ & $(0.23800)$ & $(0.04259)$ & $(0.06973)$ & (1.0) & $(0.09027)$ & $(0.06464)$ \\
\hline & {$[-6.78886]$} & [ 3.41255$]$ & {$[0.73276]$} & {$[-4.13608]$} & {$[-1.92182]$} & {$[-2.25756]$} & [ 0.46663$]$ \\
\hline \multirow[t]{3}{*}{ CointEq2 } & -0.193783 & -1.956021 & -0.067552 & 0.282213 & 1.77 & 0.179730 & -0.035948 \\
\hline & $(0.11125)$ & $(0.20002)$ & $(0.03579)$ & $(0.05860)$ & $(8.8)$ & $(0.07587)$ & $(0.05433)$ \\
\hline & {$[-1.74184]$} & {$[-9.77909]$} & {$[-1.88734]$} & [ 4.81566] & [ 2.00658] & [ 2.36896] & [-0.66169] \\
\hline \multirow[t]{3}{*}{ CointEq3 } & 1.445727 & 2.106337 & -0.084189 & -0.250879 & -5.84 & 0.157449 & 0.024342 \\
\hline & $(0.06683)$ & $(0.12015)$ & $(0.02150)$ & $(0.03520)$ & (5.3) & $(0.04557)$ & $(0.03263)$ \\
\hline & [ 21.6335] & [ 17.5307$]$ & {$[-3.91577]$} & {$[-7.12672]$} & {$[-1.10280]$} & [ 3.45482] & [ 0.74591$]$ \\
\hline
\end{tabular}


Table A.3

\begin{tabular}{|c|c|c|c|c|c|c|c|c|}
\hline 1 & 10.02983 & 0.114026160 & 21.587311 & 2.9358082441 & 0.045456697 & 15.131460389 & 0.065002724 & 60.1209345 \\
\hline 2 & 13.071 & 0.06800396 & 29.325913 & 1.78233130 & 0.028422066 & 15.4755089 & 0.082248611 & $\begin{array}{c}53.237571438266 \\
49\end{array}$ \\
\hline 4 & 17.578 & 0.5922127 & 43.4608961 & 1.17269935 & 0.48129234 & 11.2752180 & 0.62883328 & 42.3888481 \\
\hline 5 & 20.14744 & 0.6869373 & 49.7491252 & 1.04762612 & 0.42899725 & 9.4403392 & 0.572434635 & 38.0745401 \\
\hline 6 & 23.4683 & 0.59169705 & 54.6939314 & 0.81417833 & 0.316198079 & 8.4524948 & 0.53664737 & 34.5948527 \\
\hline 7 & 28.7354 & 0.4214307 & 56.5593142 & 0.59619443 & 0.21105915 & 8.3181247 & 0.79844856 & 33.095428 \\
\hline 8 & \begin{tabular}{|l|}
31.15148 \\
\end{tabular} & 0.36143329 & 59.6187071 & 0.74732058 & 0.22170857 & 7.27256188 & 1.10690764 & 30.6713608 \\
\hline
\end{tabular}

